\title{
柠檬酸络合法制备的 $\mathrm{Co} / \mathrm{CeO}_{2}$ 催化剂上中温乙醇水蒸气重整性能
}

\author{
庞潇健，陈亚中 ${ }^{*}$, 代瑞旗, 崔 鹏 \\ 合肥工业大学化工学院, 安徽合肥 230009
}

\begin{abstract}
摘要: 采用柠檬酸络合法制备了 $\mathrm{Co} / \mathrm{CeO}_{2}$ 及其钻掺杂系列催化剂, 并对催化剂进行了低温 $\mathrm{N}_{2}$ 物理吸附、 $\mathrm{X}$ 射线衍射、 $\mathrm{H}_{2}$ 程序 升温还原、傅里叶变换红外光谱、高分辨透射电镜表征以及乙醇水蒸气重整催化性能测试. 结果表明, 所制 $\mathrm{Co} / \mathrm{CeO}_{2}$ 催化剂具 有良好的乙醇水蒸气重整催化性能, $500{ }^{\circ} \mathrm{C}$ 时乙醇能全部转化为 $\mathrm{C}_{1}$, 氢气产率高达 $85 \%$ 以上. $\mathrm{Ca}$ 掺杂减小了载体 $\mathrm{CeO}_{2}$ 纳米 颗粒尺寸, 但对还原后 $\mathrm{Co}^{0}$ 尺寸的影响较小. 当 $\mathrm{Ca}$ 掺杂量大于 $5.0 \%$ 时, 催化剂氧化还原性能和乙醇水蒸气重整催化性能下 降. 较高的还原温度有利于体相 $\mathrm{Ce}^{4+}$ 还原为 $\mathrm{Ce}^{3+}$, 并且提高了催化活性, 认为金属-氧化物边界的增加提高了催化活性. 初步 稳定性考察结果表明, $5 \%$ 钻掺杂后的催化剂具有更好的抗积炭性能.
\end{abstract}

关键词: 钴; 氧化铈; 氧化钻掺杂; 柠檬酸络合; 乙醇水蒸气重整; 中温

中图分类号: O643 文献标识码: A

收稿日期: 2011-09-15. 接受日期: 2011-10-26.

*通讯联系人. 电话: (0551)2901450; 电子信箱: chenyazhong@hfut.edu.cn

基金来源：国家自然科学基金(20876030); 安徽省自然科学基金(110406Q31).

本文的英文电子版(国际版)由Elsevier出版社在ScienceDirect上出版(http://www.sciencedirect.com/science/journal/18722067).

\section{$\mathrm{Co} / \mathrm{CeO}_{2}$ Catalysts Prepared Using Citric Acid Complexing for Ethanol Steam Reforming}

\author{
PANG Xiaojian, CHEN Yazhong ${ }^{*}$, DAI Ruiqi, CUI Peng \\ School of Chemical Engineering, Hefei University of Technology, Hefei 230009, Anhui, China
}

\begin{abstract}
Co} / \mathrm{CeO}_{2}$ catalysts with and without calcium doping were prepared by the citric acid complexing method, and characterized by $\mathrm{N}_{2}$ adsorption, X-ray diffraction, temperature-programmed reduction, Fourier transform infrared spectroscopy, and high resolution transmission electron microscope. Their catalytic performance measurement for ethanol steam reforming (ESR) at $400-650{ }^{\circ} \mathrm{C}$ and atmospheric pressure with a steam-to-carbon ratio of 3.0 and gas hourly space velocity of $50000 \mathrm{ml} /(\mathrm{g} \cdot \mathrm{h})$ was measured. The citric acid complexing method enhanced metal-support interaction. The $\mathrm{Co} / \mathrm{CeO}_{2}$ catalysts gave almost $100 \%$ ethanol conversion and good hydrogen yield at $500{ }^{\circ} \mathrm{C}$. Calcium doping in the catalyst reduced the particle size of $\mathrm{CeO}_{2}$, but had little effect on the metallic cobalt size after reduction. Calcium doping higher than $5 \%$ deteriorated the redox properties and ESR catalytic performance, which was attributed to the fouling of $\mathrm{CeO}_{2}$ by $\mathrm{CaO}$. Catalysts activated at $650{ }^{\circ} \mathrm{C}$ showed a better performance, which was due to a higher reduction degree of ceria and increase of the metal-oxide interface. Stability investigation of the catalysts suggested that $5 \%$ calcium doping enhanced carbon deposition resistance.
\end{abstract}

Key words: cobalt; ceria; calcium doping; citric acid complexing; ethanol steam reforming; intermediate temperature

Received 15 September 2011. Accepted 26 October 2011.

*Corresponding author.Tel: +86-551-2901450; E-mail: chenyazhong@hfut.edu.cn

This work was supported by the National Natural Science Foundation of China (20876030) and Natural Science Foundation of Anhui Province (110406Q31).

English edition available online at Elsevier ScienceDirect (http://www.sciencedirect.com/science/journal/18722067).

Hydrogen production from various hydrocarbon and alcohol fuels has been a focus of investigation recently [1].
Bio-ethanol from the fermentation of organic matter is environmentally sustainable and benign [2]. Ethanol steam 
reforming (ESR) occurs by a complex mechanism. The following reactions take place, which include the desired ESR (Eq. 1), ethanol decomposition (Eq. 2), water gas shift (Eq. 3), ethanol dehydrogenation (Eq. 4), ethanol dehydration (Eq. 5), methanation (Eq. 6), and carbon deposition (Eqs. 7, 8).

$$
\begin{array}{lr}
\mathrm{C}_{2} \mathrm{H}_{5} \mathrm{OH}+3 \mathrm{H}_{2} \mathrm{O} \rightarrow 2 \mathrm{CO}_{2}+6 \mathrm{H}_{2} & \Delta H^{0}{ }_{298}=173.1 \mathrm{~kJ} / \mathrm{mol}(1) \\
\mathrm{C}_{2} \mathrm{H}_{5} \mathrm{OH} \rightarrow \mathrm{CO}+\mathrm{CH}_{4}+\mathrm{H}_{2} & \Delta H^{0}{ }_{298}=49 \mathrm{~kJ} / \mathrm{mol}(2) \\
\mathrm{CO}+\mathrm{H}_{2} \mathrm{O} \leftrightarrow \mathrm{CO}_{2}+\mathrm{H}_{2} & \Delta H^{0}{ }_{298}=-41 \mathrm{~kJ} / \mathrm{mol}(3) \\
\mathrm{C}_{2} \mathrm{H}_{5} \mathrm{OH} \rightarrow \mathrm{H}_{2}+\mathrm{CH}_{3} \mathrm{CHO} & \Delta H^{0}{ }_{298}=68 \mathrm{~kJ} / \mathrm{mol}(4) \\
\mathrm{C}_{2} \mathrm{H}_{5} \mathrm{OH} \rightarrow \mathrm{C}_{2} \mathrm{H}_{4}+\mathrm{H}_{2} \mathrm{O} & \Delta H^{0}{ }_{298}=45 \mathrm{~kJ} / \mathrm{mol}(5) \\
\mathrm{CO}+3 \mathrm{H}_{2} \leftrightarrow \mathrm{CH}_{4}+\mathrm{H}_{2} \mathrm{O} & \Delta H^{0}{ }_{298}=-205 \mathrm{~kJ} / \mathrm{mol}(6) \\
2 \mathrm{CO} \rightarrow \mathrm{C}+\mathrm{CO}_{2} & \Delta H^{0}{ }_{298}=-171.5 \mathrm{~kJ} / \mathrm{mol}(7) \\
\mathrm{C}_{2} \mathrm{H}_{4} \rightarrow \text { polymers } \rightarrow \text { coke } &
\end{array}
$$

Although the thermodynamics of ESR suggest a simple reaction with few byproducts, under kinetically controlled conditions, the reaction network is very complex and the product distribution depends on the catalyst used [3,4]. Supported catalysts containing $\mathrm{Ni}, \mathrm{Cu}, \mathrm{Co}$, and noble metals such as Rh, Ru, Ir, and Pt have been used for ESR [5-12]. Supported noble metal catalysts show good activity for ESR, but their high costs limit their application. A much cheaper alternative is cobalt-based catalysts, which also show good performance for ESR due to their high activity for $\mathrm{C}-\mathrm{C}$ bond cleavage and good selectivity to hydrogen at temperatures as low as $350-400{ }^{\circ} \mathrm{C}[14,15]$. For example, over a $\mathrm{Co} / \mathrm{ZnO}$ catalyst at $350{ }^{\circ} \mathrm{C}$, an ethanol conversion of $100 \%$ was achieved at gas hourly space velocity $(\mathrm{GHSV})=5000$ $\mathrm{h}^{-1}$ and steam-to-carbon ratio $(\mathrm{S} / \mathrm{C})=6.5$. These working conditions are not practical because of the high $\mathrm{S} / \mathrm{C}$ ratio and low hydrogen production rate [15]. $\mathrm{Co} / \mathrm{CeO}_{2}$ catalysts also show good resistance to carbon deposition during ESR, which has attracted much attention recently [16-18]. It was found that $\mathrm{Co} / \mathrm{CeO}_{2}$ catalysts prepared by different methods showed significant differences in ESR activity. Song et al. [18] prepared $\mathrm{Co} / \mathrm{CeO}_{2}$ catalysts using three different methods: solvothermal method, colloidal crystal templating, and reverse microemulsion. These catalysts gave much better performance than those prepared by incipient wetness impregnation. The superiority of these preparation methods was attributed to a better cobalt dispersion and enhanced metal-oxide interaction. However, these preparation methods are too complex and not practical. The citric acid complexing method is a cost effective preparation method for uniform composite oxide formation at relatively low temperatures. It gives a high yield with a simple equipment setup [19]. Catalysts prepared by this method have been applied to the partial oxidation of methane and ESR [20,21]. The present work prepared $\mathrm{Co} / \mathrm{CeO}_{2}$ catalysts by citric acid complexing. The effect of calcium doping was also investigated. In view of a recently developed membrane reformer for ESR [22-25], ESR was investigated in the temperature range of $450-650{ }^{\circ} \mathrm{C}$ at a practical GHSV.

\section{Experimental}

\subsection{Catalyst preparation}

The catalysts were prepared by the citric acid complexing method. Nitrates of cobalt, cerium, and calcium purchased from Sinopharm Chemical Reagent Co. Ltd. were utilized as starting materials without purification. A mixed solution of the nitrates with a total cation concentration of $1.0 \mathrm{~mol} / \mathrm{L}$ was prepared by dissolving the nitrates in deionized water. Citric acid was added as a complexing agent in a molar ratio of 2:1. After complete mixing and stirring at $60{ }^{\circ} \mathrm{C}$, a transparent solution was obtained. Then most of the water was evaporated at $80{ }^{\circ} \mathrm{C}$ to give a sol. A viscous gel was obtained after further stirring and evaporation. After drying at $120{ }^{\circ} \mathrm{C}$ overnight, the resulting spongy solid was heated in air in a muffle furnace from room temperature to $600{ }^{\circ} \mathrm{C}$ with a temperature ramp rate of $5{ }^{\circ} \mathrm{C} / \mathrm{min}$ and kept at $600{ }^{\circ} \mathrm{C}$ for $4.0 \mathrm{~h}$.

\subsection{Catalyst characterization}

The specific surface area, pore volume, and pore size distribution were characterized by $\mathrm{N}_{2}$ adsorption at liquid nitrogen temperature using a Quantachrome NOVA 2200E. Prior to adsorption, the samples were degassed at $350{ }^{\circ} \mathrm{C}$ for $2.0 \mathrm{~h}$ to remove physically adsorbed components. The surface area was determined from the linear portion of the Brunauer-Emmett-Teller (BET) equation. Pore volume and pore size distribution were calculated by the Barrett-Joiner-Halenda (BJH) method using the desorption branch of the isotherm.

Temperature programmed reduction (TPR) experiments were conducted on a microreactor-gas chromatograph (GC) system using a $5 \% \mathrm{H}_{2}-95 \%$ Ar atmosphere. The sample $\left(50.0 \mathrm{mg}\right.$ ) was heated from room temperature to $400{ }^{\circ} \mathrm{C}$ under $30.0 \mathrm{ml} / \mathrm{min}$ Ar flow and kept at $400{ }^{\circ} \mathrm{C}$ for at least 30 min, and then cooled down to room temperature. The Ar was switched to $30.0 \mathrm{ml} / \mathrm{min} 5 \% \mathrm{H}_{2}-95 \%$ Ar gas, and the sample was heated with a linear temperature rise from 100 to $900{ }^{\circ} \mathrm{C}$ at a rate of $10{ }^{\circ} \mathrm{C} / \mathrm{min}$. Hydrogen consumption was measured online with a thermal conductivity detector (TCD).

X-ray powder diffraction (XRD) was used to determine the phase composition and size of the catalysts before and after reduction. The XRD measurements were performed on a Rigaku D/MAX2500VL/PC apparatus using nickel filtered $\mathrm{Cu} K_{\alpha}$ radiation $(\lambda=0.1541 \mathrm{~nm})$, operating voltage of 
$40 \mathrm{kV}$ and current of $40 \mathrm{~mA}$. The crystallite sizes of the particles were measured using the peak width at half peak height and the Debye-Scherrer equation.

FT-IR spectra were recorded using a Perkin-Elmer Spectrum 100 spectrometer equipped with a deuterated triglycine sulfate detector. The spectra were collected at a resolution of $4.0 \mathrm{~cm}^{-1}$ using 32 scans in the range of $400-4000 \mathrm{~cm}^{-1}$. All the samples were prepared as $\mathrm{KBr}$ pellets.

High resolution transmission microscopy (HR-TEM) was recorded using a JEOL-2100 microscope. TEM were prepared by the ultrasonic dispersion of slightly ground catalyst samples in ethanol, and then a drop of the suspension was applied onto a holey carbon grid.

\subsection{Catalytic activity test}

Catalytic activity was measured using a fixed bed reactor of stainless steel with an inner diameter of $8.0 \mathrm{~mm}$. The catalyst $(200 \mathrm{mg})$ of $60-80$ mesh grain size were diluted with quartz sand and loaded into the reactor to achieve a catalyst bed height of $5.0 \mathrm{~mm}$. A K-type thermocouple inserted into the center of the catalyst bed was used to detect the temperature. Prior to reaction, catalysts were heated at $10{ }^{\circ} \mathrm{C} / \mathrm{min}$ in $5 \% \mathrm{H}_{2}-95 \%$ Ar flow at $30.0 \mathrm{ml} / \mathrm{min}$ from room temperature to 450 or $650{ }^{\circ} \mathrm{C}$ and kept at 450 or $650{ }^{\circ} \mathrm{C}$ for $2.0 \mathrm{~h}$. Then, ethanol, water and $\mathrm{N}_{2}$ gas were delivered to the reactor. The reaction products were monitored by an online GC equipped with TCD and flame ionization detectors (FID). $\mathrm{N}_{2}$ was used as the internal standard for calculations as well as a dilution gas. $\mathrm{CH}_{4}$ showed signals in both the TCD and FID detectors, thus the analysis of all products was obtained. Data with a carbon balance over $95 \%$ were used. Ethanol conversion was calculated by

$$
X_{\text {ethanol }}=\left(F_{\text {ethanol,in }}-F_{\text {ethanol,out }}\right) / F_{\text {ethanol,in }} \times 100 \%
$$

The yield of hydrogen was defined as the ratio between hydrogen generated (moles) and six times the ethanol fed (moles) and calculated by

$Y_{\text {hydrogen }}=$ moles of $\mathrm{H}_{2}$ produced $/(6 \times$ moles of ethanol fed $)$

$$
\times 100 \%
$$

The selectivity of carbon-containing products was calculated by

$$
S_{\mathrm{C}_{x} \mathrm{H}_{y} \mathrm{O}_{z}}=i F_{\mathrm{C}_{x} \mathrm{H}_{y} \mathrm{O}_{z}} /\left(2 F_{\text {ethanol,in }}\right) \times 100 \%
$$

where $F_{\text {ethanol,in }}$ was the flow of ethanol in the gas phase at the inlet of the reactor and $F_{\text {ethanol,out }}$ was the flow of ethanol in the gas phase at the outlet of the reactor. $F_{\text {ethanol,in }}$ was calculated from the liquid ethanol fed rate, and $F_{\text {ethanol,out }}$ was calculated using the GC analysis results and the standard gas feed rate. $\mathrm{C}_{x} \mathrm{H}_{y} \mathrm{O}_{z}$ represents carbon-containing products such as $\mathrm{CH}_{4}, \mathrm{CO}$, and $\mathrm{CO}_{2}$, and possible other products. The steam-to-carbon ratio was the molar ratio of the steam and carbon (each mole ethanol correspond to two moles carbon) flow rates at the inlet of the reactor.

\section{Results and discussion}

\subsection{Characterization}

Table 1 shows the BET specific surface area, pore volumes, and average pore sizes of the catalysts. The surface areas were not high, and the pore volumes were in the range of $0.09-0.14 \mathrm{ml} / \mathrm{g}$. The pore sizes were in the range of 7.4-10.1 nm. The low surface areas were due to the combustion reaction between the metal nitrates and citric acid during calcination, which gave a high temperature and sintering of the composite oxides.

\begin{tabular}{|c|c|c|c|}
\hline Catalyst $^{*}$ & $\begin{array}{c}\text { Surface area } \\
\left(\mathrm{m}^{2} / \mathrm{g}\right)\end{array}$ & $\begin{array}{l}\text { Pore volume } \\
(\mathrm{ml} / \mathrm{g})\end{array}$ & $\begin{array}{c}\text { Average pore size } \\
(\mathrm{nm})\end{array}$ \\
\hline $\mathrm{Co}_{0.1} \mathrm{Ce}_{0.9} \mathrm{O}_{y}$ & 8.7 & 0.09 & 10.1 \\
\hline $\mathrm{Co}_{0.1} \mathrm{Ce}_{0.85} \mathrm{Ca}_{0.05} \mathrm{O}_{y}$ & 19.4 & 0.12 & 8.5 \\
\hline $\mathrm{Co}_{0.1} \mathrm{Ce}_{0.8} \mathrm{Ca}_{0.1} \mathrm{O}_{y}$ & 18.2 & 0.11 & 7.8 \\
\hline $\mathrm{Co}_{0.1} \mathrm{Ce}_{0.75} \mathrm{Ca}_{0.15} \mathrm{O}_{y}$ & 20.3 & 0.14 & 7.4 \\
\hline
\end{tabular}

Table 1 Texture properties of $\mathrm{Co} / \mathrm{CeO}_{2}$ with and without calcium doping

*Mass ratio of atom in samples.

Figure 1 shows the XRD patterns of the $\mathrm{Co} / \mathrm{CeO}_{2}$ catalysts. Cubic $\mathrm{CeO}_{2}$ was the main phase. $\mathrm{Co}_{3} \mathrm{O}_{4}$ was not clearly seen and the $\mathrm{CaO}$ phase was not detected by XRD, suggesting its probable high dispersion on the surface of $\mathrm{CeO}_{2}$. Compared with pure $\mathrm{CeO}_{2}$, the intensity of the XRD peaks for $\mathrm{CeO}_{2}$ in the catalysts was smaller and the width of the peaks for $\mathrm{CeO}_{2}$ broader, indicating that cobalt and calcium doping resulted in the formation of $\mathrm{CeO}_{2}$ with a smaller particle size. From the Scherrer equation, the $\mathrm{CeO}_{2}$ particle sizes in $\quad \mathrm{Co}_{0.1} \mathrm{Ce}_{0.9} \mathrm{O}_{y}, \quad \mathrm{Co}_{0.1} \mathrm{Ce}_{0.85} \mathrm{Ca}_{0.05} \mathrm{O}_{y}$, $\mathrm{Co}_{0.1} \mathrm{Ce}_{0.8} \mathrm{Ca}_{0.1} \mathrm{O}_{y}$, and $\mathrm{Co}_{0.1} \mathrm{Ce}_{0.75} \mathrm{Ca}_{0.15} \mathrm{O}_{y}$ were 18.3, 14.7, 13.6, and $10.4 \mathrm{~nm}$, respectively. The $\mathrm{Co}_{3} \mathrm{O}_{4}$ cubic phase was not as clearly shown as compared with catalysts prepared by incipient wetness impregnation [16], showing that the $\mathrm{Co}_{3} \mathrm{O}_{4}$ phase was finely dispersed. After reduction at $650{ }^{\circ} \mathrm{C}$ for $2.0 \mathrm{~h}$, the $\mathrm{CeO}_{2}$ particle size, deduced from the XRD characterization, for $\quad \mathrm{Co}_{0.1} \mathrm{Ce}_{0.9} \mathrm{O}_{y}, \quad \mathrm{Co}_{0.1} \mathrm{Ce}_{0.85} \mathrm{Ca}_{0.05} \mathrm{O}_{y}$, $\mathrm{Co}_{0.1} \mathrm{Ce}_{0.8} \mathrm{Ca}_{0.1} \mathrm{O}_{y}$, and $\mathrm{Co}_{0.1} \mathrm{Ce}_{0.75} \mathrm{Ca}_{0.15} \mathrm{O}_{y}$ were 21.5, 15.8, 15.1 , and $12.2 \mathrm{~nm}$, respectively. The average particle sizes of cobalt in $\quad \mathrm{Co}_{0.1} \mathrm{Ce}_{0.9} \mathrm{O}_{y}, \quad \mathrm{Co}_{0.1} \mathrm{Ce}_{0.85} \mathrm{Ca}_{0.05} \mathrm{O}_{y}$, $\mathrm{Co}_{0.1} \mathrm{Ce}_{0.8} \mathrm{Ca}_{0.1} \mathrm{O}_{y}$, and $\mathrm{Co}_{0.1} \mathrm{Ce}_{0.75} \mathrm{Ca}_{0.15} \mathrm{O}_{y}$ calculated from the Scherrer equation were $12.8,13.1,13.4$, and $14.2 \mathrm{~nm}$, respectively, which agreed with the HR-TEM characterization results in Fig. 2.

HR-TEM characterization results are shown in Fig. 2, which also suggested the nano-structure of the $\mathrm{CeO}_{2}$ support as well as the nanostructure of $\mathrm{Co}^{0}$. The average particle 

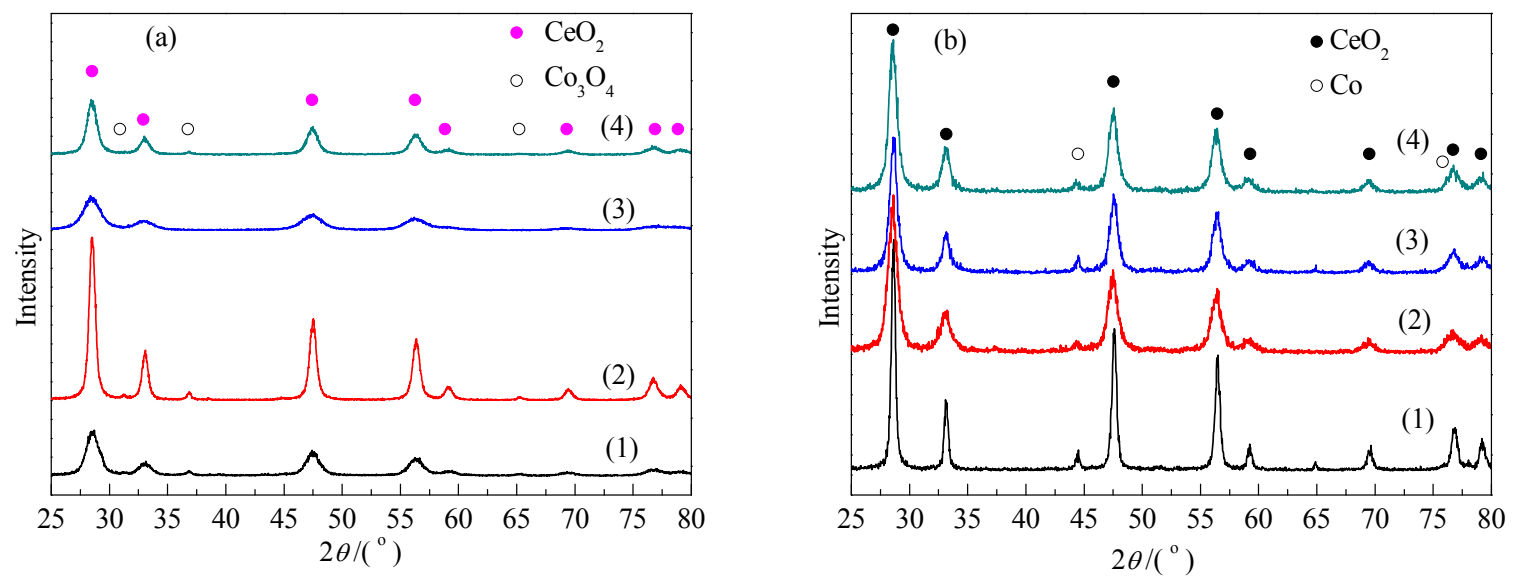

Fig. 1. XRD patterns of $\mathrm{Co} / \mathrm{CeO}_{2}$ catalysts after calcination (a) and after reduction at $650{ }^{\circ} \mathrm{C}$ (b). (1) $\mathrm{Co}_{0.1} \mathrm{Ce}_{0.9} \mathrm{O}_{y} ;$ (2) $\mathrm{Co}_{0.1} \mathrm{Ce}_{0.85} \mathrm{Ca}_{0.05} \mathrm{O}_{y} ;(3)$ $\mathrm{Co}_{0.1} \mathrm{Ce}_{0.8} \mathrm{Ca}_{0.1} \mathrm{O}_{y} ;$ (4) $\mathrm{Co}_{0.1} \mathrm{Ce}_{0.75} \mathrm{Ca}_{0.15} \mathrm{O}_{y}$.

(a)

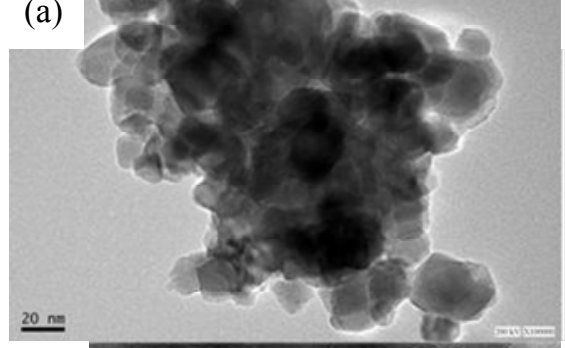

(d)

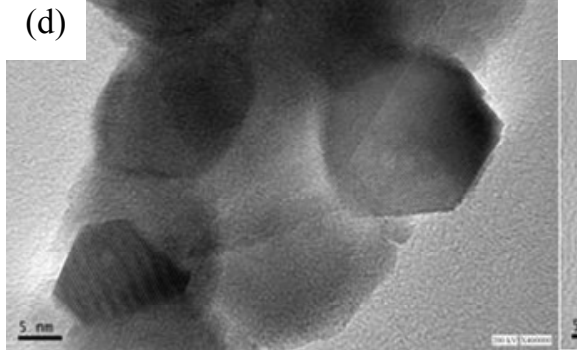

(b)

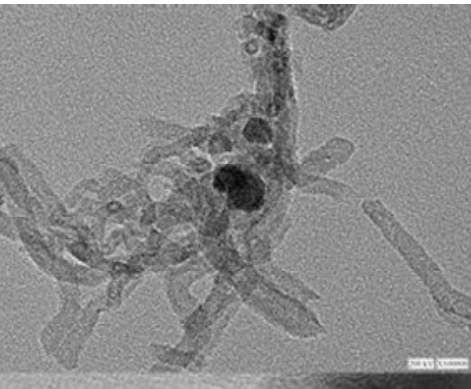

(e)

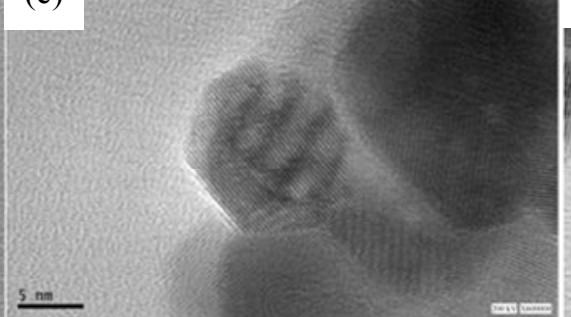

(c)

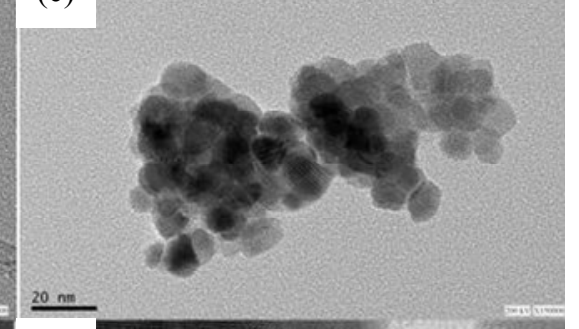

(f)

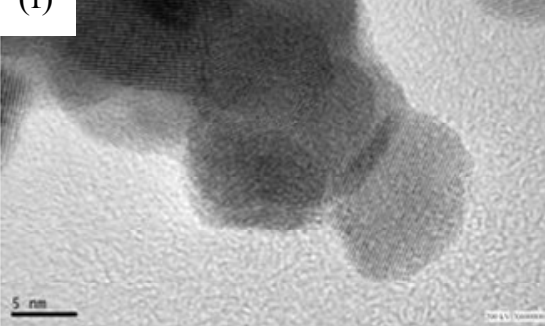

Fig. 2. TEM images of $\mathrm{Ce}_{0.9} \mathrm{Co}_{0.1} \mathrm{O}_{y}$ after reduction $(\mathrm{a}, \mathrm{d})$, used $\mathrm{Ce}_{0.9} \mathrm{Co}_{0.1} \mathrm{O}_{y}(\mathrm{~b}, \mathrm{e})$, and used $\mathrm{Co}_{0.1} \mathrm{Ce}_{0.85} \mathrm{Ca}_{0.05} \mathrm{O}_{y}(\mathrm{c}, \mathrm{f})$ catalysts.

size of $\mathrm{Co}^{0}$ (dark part) in $\mathrm{Co}_{0.1} \mathrm{Ce}_{0.9} \mathrm{O}_{y}$ after reduction was $14.0 \mathrm{~nm}$, while the particle sizes of $\mathrm{CeO}_{2}$ were in the range of 13.0-30.0 nm. The TEM characterization also suggested that $5 \%$ calcium doping had an obvious influence on ceria particle size, but little effect on cobalt particle size.

Figure 3 shows FT-IR spectra for $\mathrm{Co}_{0.1} \mathrm{Ce}_{0.9} \mathrm{O}_{y}$, $\mathrm{Co}_{0.1} \mathrm{Ce}_{0.85} \mathrm{Ca}_{0.05} \mathrm{O}_{y}, \mathrm{Co}_{0.1} \mathrm{Ce}_{0.8} \mathrm{Ca}_{0.1} \mathrm{O}_{y}$, and $\mathrm{Co}_{0.1} \mathrm{Ce}_{0.75} \mathrm{Ca}_{0.15} \mathrm{O}_{y}$ in the wave number range of $500-4000 \mathrm{~cm}^{-1}$. The FT-IR characterization gave information on two problems. The first was the effect of calcium addition into $\mathrm{Co} / \mathrm{CeO}_{2}$ on carbonate formation. Figure 3(a) clearly indicated that too much calcium (15.0 wt\%) addition caused much carbonate formation, which was shown by the FT-IR peaks at 1419 and $870 \mathrm{~cm}^{-1}$. Thus, it was deduced that too much calcium doping would cause acetate formation during ESR, which is believed to be one of the reasons for catalyst deactivation [28].
Figure 3(b) shows the IR region in which superoxide $\mathrm{O}_{2}^{-}$ was detected. Oxygen storage begins with the activation of gaseous $\mathrm{O}_{2}$ molecules on $\mathrm{O}$ vacancies associated with reduced cerium sites $\left(\mathrm{Ce}^{3+}\right)$, known as coordinatively unsaturated sites (CUS) on the surface of the composite oxide $[29,30]$. This activation results in the formation of $\mathrm{O}$ radicals upon exposure of the surface to $\mathrm{O}_{2}$, due to the reduction of $\mathrm{O}_{2}$ and subsequently oxidation of the $\mathrm{Ce}^{3+}$ CUS. Among the various $\mathrm{O}$ radicals that can be progressively formed, the $\mathrm{O}_{2}^{-}$is very stable and it is considered a key species or an oxygen storage initiator for both surface and bulk storage $[29,30] . \mathrm{O}_{2}^{-}$radicals can be detected by FT-IR [31]. The band at $1121 \mathrm{~cm}^{-1}$ was assigned to the superoxide species. This band was observed with $\mathrm{Co}_{0.1} \mathrm{Ce}_{0.9} \mathrm{O}_{y}$ and $\mathrm{Co}_{0.1} \mathrm{Ce}_{0.85} \mathrm{Ca}_{0.05} \mathrm{O}_{y}$, but not with $\mathrm{Co}_{0.1} \mathrm{Ce}_{0.8} \mathrm{Ca}_{0.1} \mathrm{O}_{y}$ and $\mathrm{Co}_{0.1} \mathrm{Ce}_{0.75} \mathrm{Ca}_{0.15} \mathrm{O}_{y}$. The results indicated that too much calcium doping into $\mathrm{Co} / \mathrm{CeO}_{2}$ through citric acid complexing 

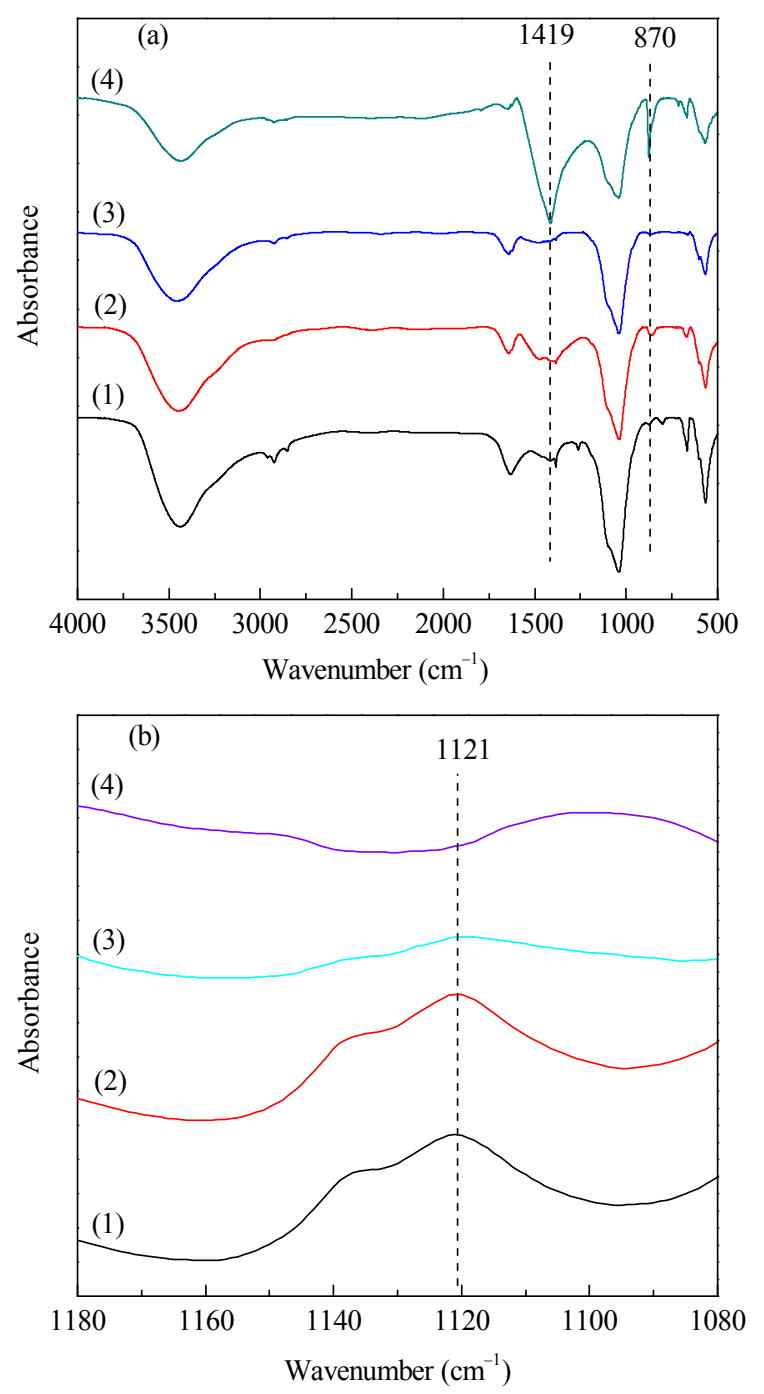

Fig. 3. FT-IR characterization of $\mathrm{Co} / \mathrm{CeO}_{2}$ with and without calcium doping. (a) FT-IR spectra in the range $500-4000 \mathrm{~cm}^{-1}$; (b) IR spectra of $\mathrm{O}_{2}^{-}$in the range $1080-1180 \mathrm{~cm}^{-1}$. (1) $\mathrm{Co}_{0.1} \mathrm{Ce}_{0.9} \mathrm{O}_{y}$; (2) $\mathrm{Co}_{0.1} \mathrm{Ca}_{0.05} \mathrm{Ce}_{0.85} \mathrm{O}_{y} ;$ (3) $\mathrm{Co}_{0.1} \mathrm{Ca}_{0.1} \mathrm{Ce}_{0.8} \mathrm{O}_{y} ;$ (4) $\mathrm{Co}_{0.1} \mathrm{Ca}_{0.15} \mathrm{Ce}_{0.75} \mathrm{O}_{y}$.

deteriorated its oxygen storage capacity, which is detrimental to surface oxygen reduction. As the formation of the $\mathrm{Ce}^{3+}-\mathrm{O}-\mathrm{Co}^{0}$ metal-oxide interface has been proposed as necessary for the active sites for ESR by Chen [26] and de Lima [27], thus the ESR catalytic performance was affected by the particle size of the cobalt and ceria, as well as the reduction degree of $\mathrm{Ce}^{4+}$. Calcium doping hindered the sintering of the ceria support by its isolation of small ceria particles during calcination, but it also affected $\mathrm{Ce}^{3+}-\mathrm{O}-\mathrm{Co}^{0}$ metal-oxide interface formation and ESR catalytic performance.

Figure 4 shows the $\mathrm{H}_{2}$-TPR spectra for $\mathrm{Co}_{3} \mathrm{O}_{4}, \mathrm{CeO}_{2}$, $\mathrm{Co}_{0.1} \mathrm{Ce}_{0.9} \mathrm{O}_{y}, \quad \mathrm{Co}_{0.1} \mathrm{Ce}_{0.8} \mathrm{Ca}_{0.1} \mathrm{O}_{y}, \quad \mathrm{Co}_{0.1} \mathrm{Ce}_{0.85} \mathrm{Ca}_{0.05} \mathrm{O}_{y}$, and $\mathrm{Co}_{0.1} \mathrm{Ce}_{0.75} \mathrm{Ca}_{0.15} \mathrm{O}_{y}$. The overlapping peak in Fig. 4 after Gaussian deconvolution suggested that $\mathrm{Co}_{3} \mathrm{O}_{4}$ reduction

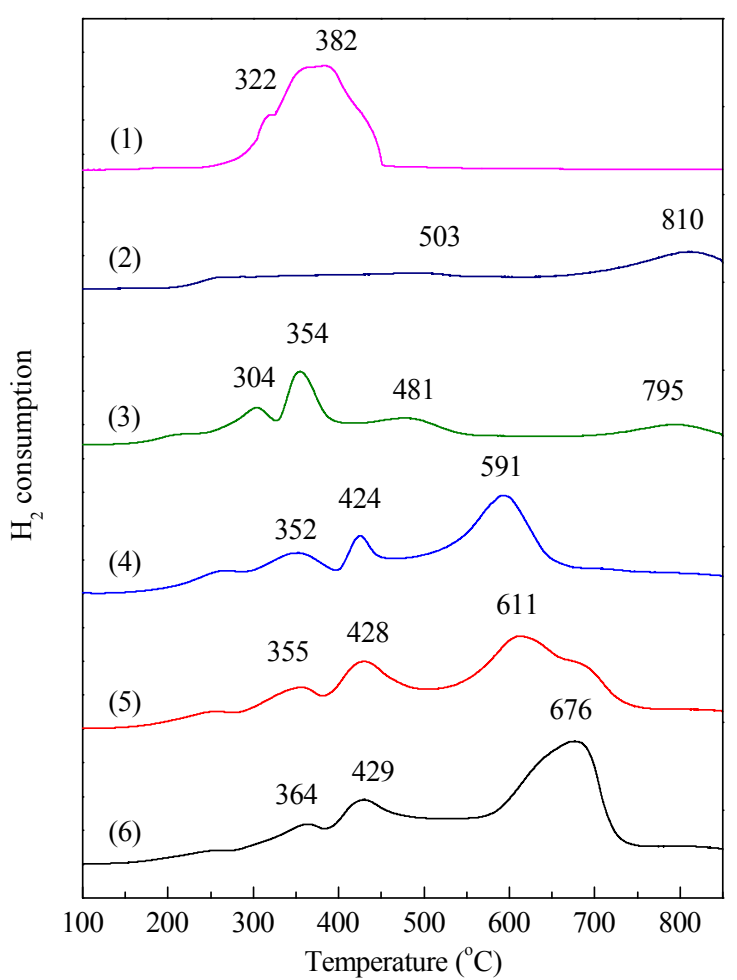

Fig. 4. $\mathrm{H}_{2}-\mathrm{TPR}$ profiles of $\mathrm{Co} / \mathrm{CeO}_{2}$ catalysts with and without calcium doping. (1) $\mathrm{Co}_{3} \mathrm{O}_{4} ; \quad$ (2) $\mathrm{CeO}_{2} ; \quad$ (3) $\mathrm{Co}_{0.1} \mathrm{Ce}_{0.9} \mathrm{O}_{y}$; (4) $\mathrm{Co}_{0.1} \mathrm{Ca}_{0.05} \mathrm{Ce}_{0.85} \mathrm{O}_{y} ;$; (5) $\mathrm{Co}_{0.1} \mathrm{Ca}_{0.1} \mathrm{Ce}_{0.8} \mathrm{O}_{y} ;(6) \mathrm{Co}_{0.1} \mathrm{Ca}_{0.15} \mathrm{Ce}_{0.75} \mathrm{O}_{y}$.

proceeded by two steps: first the reduction of $\mathrm{Co}^{3+}$ to $\mathrm{Co}^{2+}$ and then of $\mathrm{Co}^{2+}$ to $\mathrm{Co}^{0}$. The first reduction peak temperature at $320{ }^{\circ} \mathrm{C}$ was assigned to the reduction of $\mathrm{Co}^{3+}$ to $\mathrm{Co}^{2+}$ and the second at $380{ }^{\circ} \mathrm{C}$ was attributed to $\mathrm{Co}^{2+}$ reduction to $\mathrm{Co}^{0}$. With ceria, two reduction peaks were observed. The first broad peak at $400{ }^{\circ} \mathrm{C}$ was attributed to the reduction of surface and subsurface $\mathrm{Ce}^{4+}$ to $\mathrm{Ce}^{3+}$, and the second peak at $800{ }^{\circ} \mathrm{C}$ was due to the reduction of bulk $\mathrm{Ce}^{4+}$. For $\mathrm{Co}_{0.1} \mathrm{Ce}_{0.9} \mathrm{O}_{y}$, the interaction of $\mathrm{Co}_{3} \mathrm{O}_{4}$ and $\mathrm{CeO}_{2}$ benefited the reduction of $\mathrm{Co}^{3+}$ to $\mathrm{Co}^{2+}$ and $\mathrm{Ce}^{4+}$ to $\mathrm{Ce}^{3+}$. During $\mathrm{Co}_{3} \mathrm{O}_{4}$ reduction of $\mathrm{Co}_{0.1} \mathrm{Ce}_{0.9} \mathrm{O}_{y}$, the peak temperature for $\mathrm{Co}^{3+}$ reduction to $\mathrm{Co}^{2+}$ was decreased from 322 to $304{ }^{\circ} \mathrm{C}$. For some of the surface $\mathrm{Co}_{3} \mathrm{O}_{4}$, the reduction temperature was as low as $250{ }^{\circ} \mathrm{C}$. The peak temperature for $\mathrm{Co}^{2+}$ reduction to $\mathrm{Co}^{0}$ was decreased from 382 to $354{ }^{\circ} \mathrm{C}$, suggesting a close interaction between $\mathrm{Co}_{3} \mathrm{O}_{4}$ and $\mathrm{CeO}_{2}$. Calcium doping of the catalysts would increase their sintering resistance during the ESR reaction. However, it was detrimental for $\mathrm{Co}_{3} \mathrm{O}_{4}$ and $\mathrm{CeO}_{2}$ reduction and $\mathrm{Ce}^{3+}-\mathrm{O}-\mathrm{Co}^{0}$ formation. Calcium doping hindered the interaction between $\mathrm{Co}_{3} \mathrm{O}_{4}$ and $\mathrm{CeO}_{2}$ to some extent, which was shown in the $\mathrm{H}_{2}-\mathrm{TPR}$ characterization results. Calcium $(5.0 \%)$ doping increased the peak temperature for $\mathrm{Co}^{3+}$ reduction to $\mathrm{Co}^{2+}$ from 304 to $352{ }^{\circ} \mathrm{C}$, and $\mathrm{Co}^{2+}$ reduction to $\mathrm{Co}^{0}$ from 354 to $424{ }^{\circ} \mathrm{C}$. With the increase of calcium doping content, the reduction tem- 
perature shifted to higher temperatures, indicating that calcium doping weakened the interaction between $\mathrm{Co}_{3} \mathrm{O}_{4}$ and $\mathrm{CeO}_{2}$. These results are not in agreement with the findings by Song et al. [32] who doped $5.0 \%$ calcium into $\mathrm{CeO}_{2}$ by coprecipitation, and then prepared calcium doped $\mathrm{Co} / \mathrm{CeO}_{2}$ by incipient wetness impregnation. They found that $5 \%$ calcium doping of the catalysts benefited the reduction of $\mathrm{Co}_{3} \mathrm{O}_{4}$ as well as $\mathrm{CeO}_{2}$. This significant difference was attributed to the preparation methods. In the impregnation method, $\mathrm{Co}_{3} \mathrm{O}_{4}$ is supported on the surface of $\mathrm{CeO}_{2}$, and calcium doping mainly influenced the properties of $\mathrm{CeO}_{2}$, but had little effect on the interaction between $\mathrm{Co}_{3} \mathrm{O}_{4}$ and $\mathrm{CeO}_{2}$. For the $\mathrm{Co} / \mathrm{CeO}_{2}$ catalysts prepared by citric acid complexing, calcium doping was shown to influence the interaction between $\mathrm{CeO}_{2}$ and $\mathrm{Co}_{3} \mathrm{O}_{4}$ by FT-IR and TEM characterization. Moreover, calcium doping also hindered the promoting effect of $\mathrm{Co}_{3} \mathrm{O}_{4}$ on $\mathrm{CeO}_{2}$ reduction, as shown by the TPR characterization in which the peak temperature for bulk $\mathrm{CeO}_{2}$ reduction increased from 591 to $676{ }^{\circ} \mathrm{C}$ when the calcium content increased from $5.0 \%$ to $15.0 \%$.

\subsection{Catalytic performance}

The influence of pre-reduction temperature on catalytic performance was investigated. Two temperatures, 450 and $650{ }^{\circ} \mathrm{C}$, were chosen from the $\mathrm{H}_{2}$-TPR characterization results. The two temperatures were chosen according to the following consideration. $\mathrm{Co}_{3} \mathrm{O}_{4}$ and surface $\mathrm{CeO}_{2}$ can be reduced at $450{ }^{\circ} \mathrm{C}$, while $\mathrm{Co}_{3} \mathrm{O}_{4}$, surface and some bulk $\mathrm{CeO}_{2}$ can be reduced at $650{ }^{\circ} \mathrm{C}$. The catalytic performance of $\mathrm{Co}_{0.1} \mathrm{Ce}_{0.9} \mathrm{O}_{y}, \mathrm{Co}_{0.1} \mathrm{Ce}_{0.85} \mathrm{Ca}_{0.05} \mathrm{O}_{y}, \mathrm{Co}_{0.1} \mathrm{Ce}_{0.8} \mathrm{Ca}_{0.1} \mathrm{O}_{y}$, and $\mathrm{Co}_{0.1} \mathrm{Ce}_{0.75}-\mathrm{Ca}_{0.15} \mathrm{O}_{y}$ activated at 450 and $650{ }^{\circ} \mathrm{C}$ are shown in Fig. 5. The catalysts activated at $650{ }^{\circ} \mathrm{C}$ gave better performance in terms of ethanol conversion. For example, with $\mathrm{Co}_{0.1} \mathrm{Ce}_{0.85} \mathrm{Ca}_{0.05} \mathrm{O}_{y}$ catalyst activated at $450{ }^{\circ} \mathrm{C}$, ethanol was not efficiently converted at $400{ }^{\circ} \mathrm{C}$, while with $\mathrm{Co}_{0.1} \mathrm{Ce}_{0.9} \mathrm{O}_{y}$ catalyst activated at $650{ }^{\circ} \mathrm{C}$, ethanol conversion reached $40.5 \%$ at $400{ }^{\circ} \mathrm{C}$. Similar trends were observed for the $\mathrm{Co}_{0.1} \mathrm{Ce}_{0.9} \mathrm{O}_{y}, \mathrm{Co}_{0.1} \mathrm{Ce}_{0.8} \mathrm{Ca}_{0.1} \mathrm{O}_{y}$, and $\mathrm{Co}_{0.1} \mathrm{Ce}_{0.75} \mathrm{Ca}_{0.15} \mathrm{O}_{y}$ catalysts, with much higher ethanol conversions from catalysts activated at $650{ }^{\circ} \mathrm{C}$ than from those activated at $450{ }^{\circ} \mathrm{C}$ when the reaction temperature was in the range of 400-500 ${ }^{\circ} \mathrm{C}$. However, when the reaction temperature was over 550 ${ }^{\circ} \mathrm{C}$, ethanol conversion was not very different for catalysts activated at 450 and $650{ }^{\circ} \mathrm{C}$. The result is related to in situ reduction of the catalysts under working conditions. The hydrogen content in the reformate increased with ethanol conversion, and the in situ generated hydrogen can be utilized as a reduction agent for catalyst reduction.

The catalytic performance of the catalysts confirmed the FT-IR and $\mathrm{H}_{2}$-TPR characterization results, which suggested that $>5 \%$ calcium doping resulted in deteriorated oxygen storage capacity. The oxygen storage capacity of $\mathrm{Co} / \mathrm{CeO}_{2}$ has a significant effect on ESR according to the reaction mechanism proposed by de Lima [27]. The diffuse reflection infrared Fourier transform spectroscopy (DRIFTS) characterization of ethanol desorption and DRIFTS under reaction conditions showed a junction effect between metal and support. Ethoxy species were generated on the surface of partially reduced ceria by dissociative adsorption. Oxidative dehydrogenation occurred with surface $-\mathrm{OH}$ on the support to form an acetate intermediate, liberating $\mathrm{H}_{2}$ in the process at the support-metal interface [33]. During oxidation and oxidative steam reforming, the dehydrogenated species can react with oxygen species from the support to produce acetate species. In the presence of co-adsorbed steam, the acetate decomposition reaction is favored, generating $\mathrm{CO}_{x}$ and $\mathrm{CH}_{x}$. Calcium doping decreased the catalytic activity, although the particle size of ceria $\mathrm{CeO}_{2}$ was decreased and that of $\mathrm{Co}^{0}$ was not changed. The decreased catalytic performance was probably due to $\mathrm{CaO}$ fouling of $\mathrm{CeO}_{2}$ and the smaller $\mathrm{Ce}^{3+}$-Co interface [34].

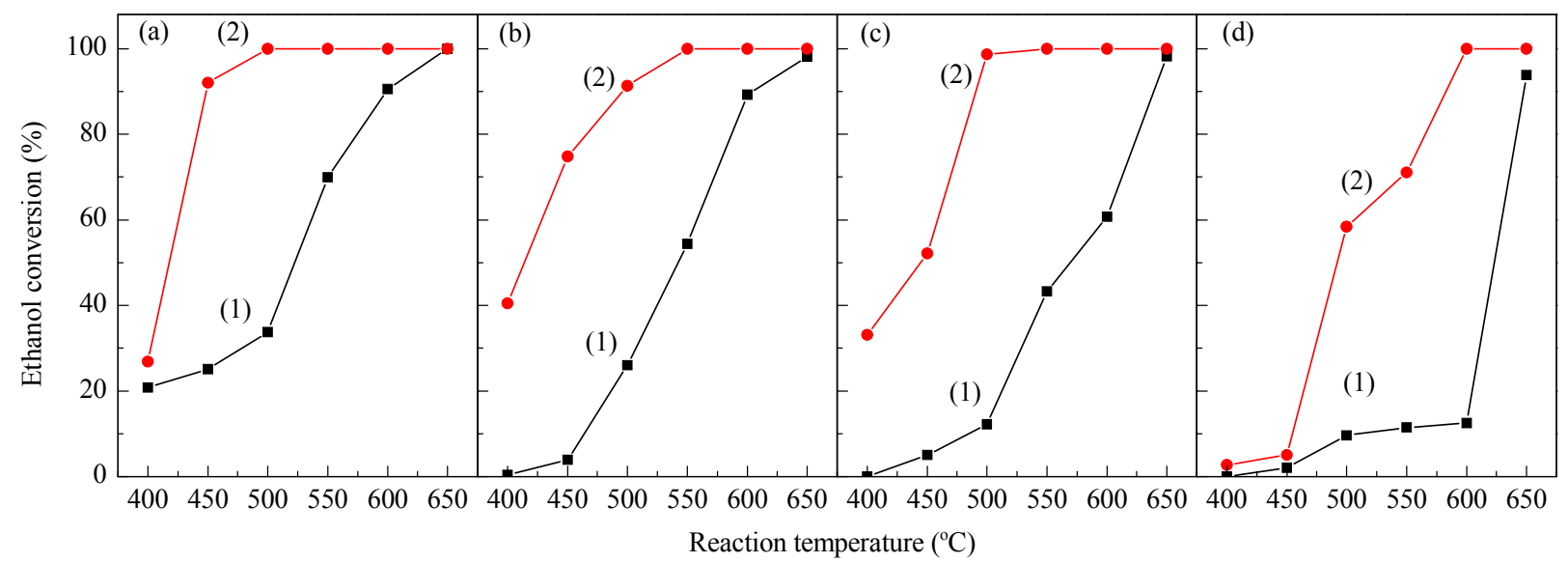

Fig. 5. Catalytic performance for catalysts activated at $450{ }^{\circ} \mathrm{C}(1)$ and $650{ }^{\circ} \mathrm{C}$ (2) for ethanol steam reforming. (a) $\mathrm{Co}_{0.1} \mathrm{Ce}_{0.9} \mathrm{O}_{y} ;\left(\right.$ b) $\mathrm{Co}_{0.1} \mathrm{Ca}_{0.05} \mathrm{Ce}_{0.85} \mathrm{O}_{y}$; (c) $\mathrm{Co}_{0.1} \mathrm{Ca}_{0.1} \mathrm{Ce}_{0.8} \mathrm{O}_{y} ;$ (d) $\mathrm{Co}_{0.1} \mathrm{Ca}_{0.15} \mathrm{Ce}_{0.75} \mathrm{O}_{y}$. Reaction conditions: GHSV $=50000 \mathrm{ml} /(\mathrm{g} \cdot \mathrm{h}), \mathrm{C}_{2} \mathrm{H}_{5} \mathrm{OH}:$ water: $\mathrm{N}_{2}=1: 6: 18, p=101 \mathrm{kPa}$. 

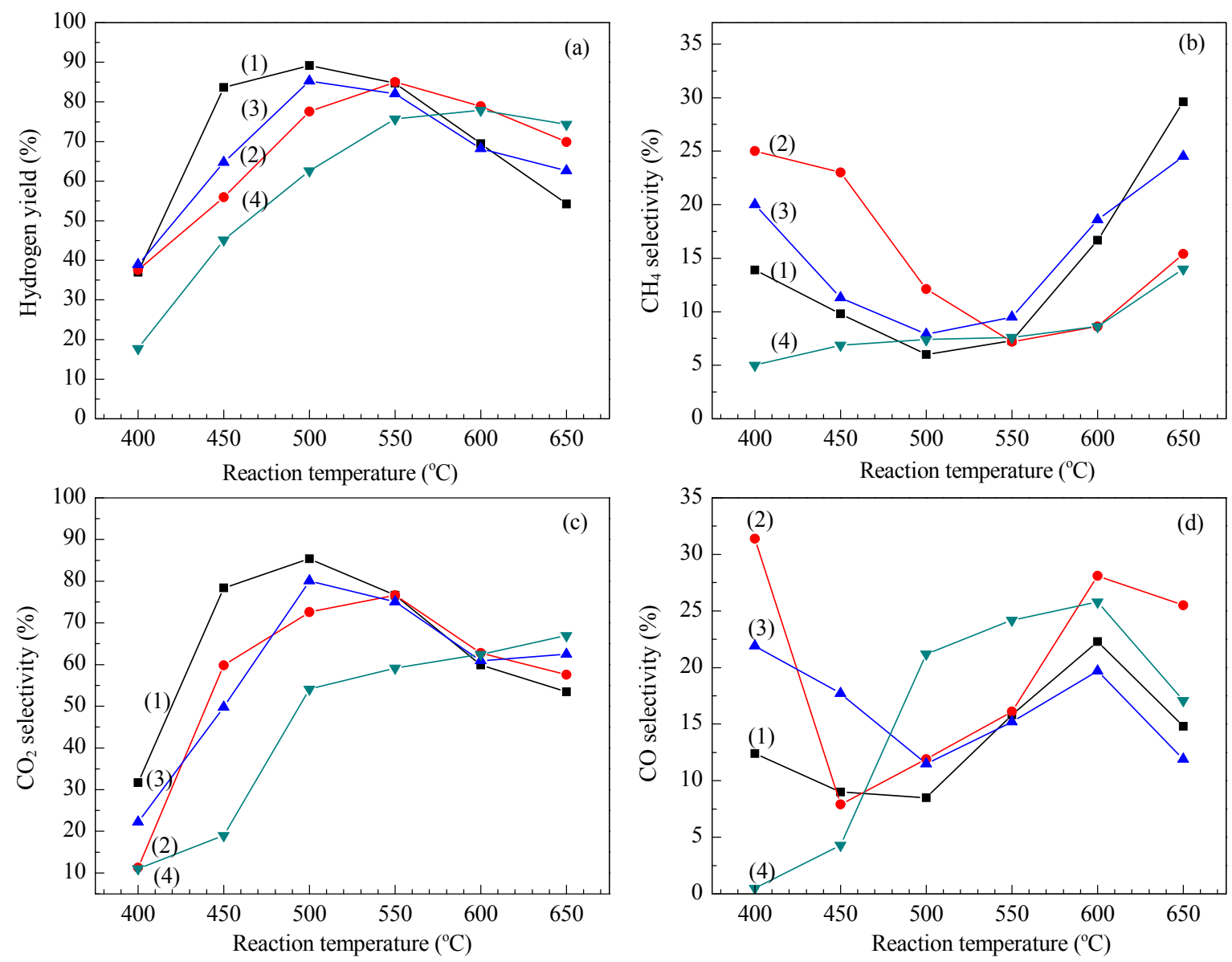

Fig. 6. Selectivity and hydrogen yield over different catalysts reduced at $650{ }^{\circ} \mathrm{C}$. (a) Hydrogen yield; (b) $\mathrm{CH}_{4}$ selectivity; (c) $\mathrm{CO}_{2}$ selectivity; (d) $\mathrm{CO}$ selectivity. (1) $\mathrm{Co}_{0.1} \mathrm{Ce}_{0.9} \mathrm{O}_{y} ;$; (2) $\mathrm{Co}_{0.1} \mathrm{Ca}_{0.05} \mathrm{Ce}_{0.85} \mathrm{O}_{y}$; (3) $\mathrm{Co}_{0.1} \mathrm{Ca}_{0.1} \mathrm{Ce}_{0.8} \mathrm{O}_{y}$; (4) $\mathrm{Co}_{0.1} \mathrm{Ca}_{0.15} \mathrm{Ce}_{0.75} \mathrm{O}_{y}$. Reaction conditions: GHSV $=50000 \mathrm{ml} /(\mathrm{g} \cdot \mathrm{h}$ ), $\mathrm{C}_{2} \mathrm{H}_{5} \mathrm{OH}:$ water: $\mathrm{N}_{2}=1: 6: 18, p=101 \mathrm{kPa}$.

Figure 6 shows the selectivity to $\mathrm{CO}_{2}, \mathrm{CO}, \mathrm{CH}_{4}$, and hydrogen for $\quad \mathrm{Co}_{0.1} \mathrm{Ce}_{0.9} \mathrm{O}_{y}, \quad \mathrm{Co}_{0.1} \mathrm{Ce}_{0.85} \mathrm{Ca}_{0.05} \mathrm{O}_{y}$, $\mathrm{Co}_{0.1} \mathrm{Ce}_{0.8} \mathrm{Ca}_{0.1} \mathrm{O}_{y}$, and $\mathrm{Co}_{0.1} \mathrm{Ce}_{0.75} \mathrm{Ca}_{0.15} \mathrm{O}_{y}$ catalysts reduced at $650{ }^{\circ} \mathrm{C}$. At low temperatures, ethanol was not completely converted into $\mathrm{C}_{1}$ species. $\mathrm{CH}_{3} \mathrm{CHO}$ and $\mathrm{CH}_{3} \mathrm{COCH}_{3}$ were observed in products. With increasing reaction temperature to over $450{ }^{\circ} \mathrm{C}$, there was no $\mathrm{CH}_{3} \mathrm{CHO}$ and $\mathrm{CH}_{3} \mathrm{COCH}_{3}$ in the product, and ethanol was completely converted into $\mathrm{C}_{1}$ species. The product distribution was kinetically controlled and depended on reaction temperature and catalyst. During ESR, water gas shift (WGS) and methanation also occurred. To get a good hydrogen yield, a catalyst with good activity for both the ESR and WGS reactions is desired. The $\mathrm{Co}_{0.1} \mathrm{Ce}_{0.9} \mathrm{O}_{y}$ catalyst showed high WGS activity, and the highest selectivities for $\mathrm{CO}_{2}$ were obtained at temperatures below $550{ }^{\circ} \mathrm{C}$. However, at 600 and $650{ }^{\circ} \mathrm{C}$, the selectivities for $\mathrm{CO}_{2}$ over the $\mathrm{Co}_{0.1} \mathrm{Ce}_{0.9} \mathrm{O}_{y}$ catalyst was slightly lower than those over the other catalysts, which were attributed to the higher activity for the WGS and also reverse WGS reactions of the $\mathrm{Co}_{0.1} \mathrm{Ce}_{0.9} \mathrm{O}_{y}$ catalyst. Thus, the selectivity for $\mathrm{CO}_{2}$ over $\mathrm{Co}_{0.1} \mathrm{Ce}_{0.9} \mathrm{O}_{y}$ was thermodynamically controlled, while over the other catalysts, it was kinetically controlled. The selectivity for $\mathrm{CH}_{4}$ was also found to depend on the catalyst and reaction temperature. At $500{ }^{\circ} \mathrm{C}$, a lower selectivity for $\mathrm{CH}_{4}$ was obtained with all the catalysts. According to Eq. (6), each mole of $\mathrm{CH}_{4}$ formation consumes three moles hydrogen, and a lower selectivity for $\mathrm{CH}_{4}$ would give a higher hydrogen yield. $\mathrm{CH}_{4}$ formation proceeds through two routes: ethanol direct decomposition and methanation. At low reaction temperature, ethanol direct decomposition dominates. However, at high temperatures, $\mathrm{CH}_{4}$ steam reforming instead of methanation dominates. The selectivity for $\mathrm{CH}_{4}$ was closely related with methane steam reforming and ethanol decomposition. Hydrogen yields over the different catalysts are also shown in Fig. 6(a). Over the $\mathrm{Co}_{0.1} \mathrm{Ce}_{0.9} \mathrm{O}_{y}$ catalyst, a hydrogen yield of $89.2 \%$ was obtained at $500{ }^{\circ} \mathrm{C}$. The selectivities for $\mathrm{CH}_{4}, \mathrm{CO}$, and $\mathrm{CO}_{2}$ were $6.0 \%, 8.5 \%$, and $85.5 \%$, respectively. At lower temperatures, side products such as acetaldehyde and acetone decreased the hydrogen yield, and less than $50 \%$ hydrogen yield were obtained. A high reaction temperature also decreased hydrogen yield due to a higher selectivity for CO. A 
temperature around $500{ }^{\circ} \mathrm{C}$ was the best, where hydrogen yields over $85 \%$ were obtained over all the catalysts. On comparing the hydrogen yield over different catalysts, it can be concluded that calcium doping significantly decreased hydrogen yield below $500{ }^{\circ} \mathrm{C}$ due to its hindrance effect on the interaction between $\mathrm{CeO}_{2}$ and $\mathrm{Co}_{3} \mathrm{O}_{4}$ and a lower oxygen storage capacity. However, at temperatures above 550 ${ }^{\circ} \mathrm{C}$, slightly higher hydrogen yields were obtained over the doped catalysts, which can be attributed to the slightly lower selectivity for CO, as shown in Fig. 6.

As shown by the characterization, activation, and catalytic performance of the catalysts, the catalysts for ESR should have small crystallites of the metallic cobalt active phase and easily reducible and accessible $\mathrm{Ce}^{3+}$ for steam adsorption. On the surface of metallic cobalt, activation of ethanol occurs, while over partially reduced ceria, activation of water occurred. The close contact of both components and a short enough distance from the boundary to the center of the surface of cobalt crystallites have a significant influence on ESR. The reagents and reaction intermediates chemisorbed on cobalt and on the ceria support have to interact to form the desired products of ESR: hydrogen and carbon dioxide. If the distance from the cobalt-support boundary is too large (it is the case with large cobalt crystallites) and since water is not strongly activated on the support, a non-selective transformation of ethanol takes place without the possibility that the by-products or intermediates can react with activated water from the support. Under this circumstance, it is possible to obtain $100 \%$ ethanol conversion to acetaldehyde as the primary product over the cobalt surface. Due to a low surface concentration of activated water adsorbed on the support near the cobalt-support border, much acetaldehyde remains in the final product. There is no further reaction of acetaldehyde with water to form the desired products $\left(\mathrm{CH}_{3} \mathrm{CHO}+\mathrm{H}_{2} \mathrm{O} \rightarrow 3 \mathrm{H}_{2}+2 \mathrm{CO}\right.$ or
$\mathrm{CH}_{3} \mathrm{CHO}+3 \mathrm{H}_{2} \mathrm{O} \rightarrow 5 \mathrm{H}_{2}+2 \mathrm{CO}_{2}$ ). Similarly, for the same reason, acetone remains in the product. Large crystallites of cobalt, a large distance from the cobalt-support boundary to the center, low concentration of activated water on the support, and the chemical nature of the support result in a low rate of WGS. Carbon monoxide can be formed on the cobalt active phase by the direct decomposition of ethanol (eq. 2) or acetaldehyde $\left(\mathrm{CH}_{3} \mathrm{CHO} \rightarrow \mathrm{CO}+\mathrm{CH}_{4}\right)$ and by the steam reforming of ethanol and acetaldehyde $\left(\mathrm{C}_{2} \mathrm{H}_{5} \mathrm{OH}+\mathrm{H}_{2} \mathrm{O} \rightarrow\right.$ $2 \mathrm{CO}+4 \mathrm{H}_{2}, \mathrm{CH}_{3} \mathrm{CHO}+\mathrm{H}_{2} \mathrm{O} \rightarrow 3 \mathrm{H}_{2}+2 \mathrm{CO}$ ) when the water concentration is insufficient [35-37]. A small contribution of the WGS reaction to the ESR pathway on these catalysts results also in low selectivities towards hydrogen and carbon dioxide when compared with thermodynamic values.

\subsection{Stability}

The stabilities of the $\mathrm{Co}_{0.1} \mathrm{Ce}_{0.85} \mathrm{Ca}_{0.05} \mathrm{O}_{y}$ and $\mathrm{Co}_{0.1} \mathrm{Ce}_{0.9} \mathrm{O}_{y}$ catalysts were investigated. The results are shown in Fig. 7. During $50.0 \mathrm{~h}$ on stream, the ethanol conversion was maintained at almost $100 \%$, and hydrogen selectivity of $85 \%$, and selectivities for $\mathrm{CH}_{4}, \mathrm{CO}$, and $\mathrm{CO}_{2}$ of $8.0 \%, 16.0 \%$, and $76.0 \%$ were maintained. TEM characterization of reduced $\mathrm{Co}_{0.1} \mathrm{Ce}_{0.85} \mathrm{Ca}_{0.05} \mathrm{O}_{y}$ and the used catalyst showed no obvious sintering of cobalt and ceria in the $\mathrm{Co}_{0.1} \mathrm{Ce}_{0.85} \mathrm{Ca}_{0.05} \mathrm{O}_{y}$ catalyst. The good stability was closely related to the working conditions as well as the catalyst itself. A S/C of 3.0 prevents carbon deposition. HRTEM characterization of the used catalysts also showed that no carbon deposition occurred. The weak basic property of the catalyst efficiently prevented ethanol dehydration to ethylene, which is believed to be a carbon deposition source. Although both the $\mathrm{Co}_{0.1} \mathrm{Ce}_{0.9} \mathrm{O}_{y}$ and $\mathrm{Co}_{0.1} \mathrm{Ce}_{0.85} \mathrm{Ca}_{0.05} \mathrm{O}_{y}$ catalysts maintained their activity and product selectivities during $50.0 \mathrm{~h}$ on

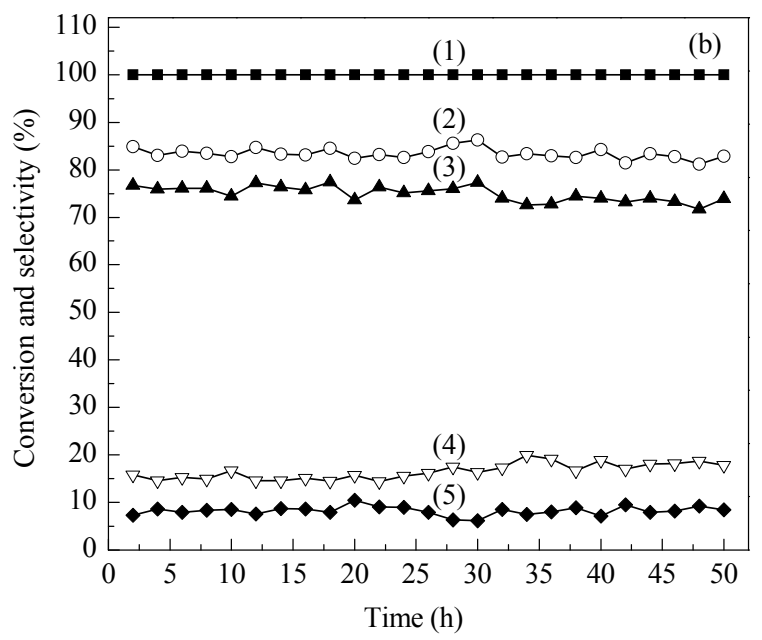

Fig. 7. Stability test of $\mathrm{Co}_{0.1} \mathrm{Ce}_{0.85} \mathrm{Ca}_{0.05} \mathrm{O}_{y}$ (a) and $\mathrm{Co}_{0.1} \mathrm{Ce}_{0.9} \mathrm{O}_{y}$ (b) catalysts. Reaction conditions: $T=550{ }^{\circ} \mathrm{C}, \mathrm{S} / \mathrm{C}=3.0, \mathrm{GHSV}=50000 \mathrm{ml} /(\mathrm{g} \cdot \mathrm{h})$, $\mathrm{C}_{2} \mathrm{H}_{5} \mathrm{OH}: \mathrm{H}_{2} \mathrm{O}: \mathrm{N}_{2}=1: 6: 18, p=101 \mathrm{kPa}$. (1) Ethanol conversion; (2) $\mathrm{H}_{2}$ selectivity; (3) $\mathrm{CO}_{2}$ selectivity; (4) $\mathrm{CO}$ selectivity; (5) $\mathrm{CH}_{4}$ selectivity. 
stream, TEM images of the used $\mathrm{Co}_{0.1} \mathrm{Ce}_{0.9} \mathrm{O}_{y}$ and $\mathrm{Co}_{0.1} \mathrm{Ce}_{0.85} \mathrm{Ca}_{0.05} \mathrm{O}_{y}$ catalysts (shown in Fig. 2) indicated that whisker carbon deposition has occurred on the $\mathrm{Co}_{0.1} \mathrm{Ce}_{0.9} \mathrm{O}_{y}$ catalyst, while this not seen on the $\mathrm{Co}_{0.1} \mathrm{Ce}_{0.85} \mathrm{Ca}_{0.05} \mathrm{O}_{y}$. Calcium doping increased the resistance to carbon deposition of the catalyst, which was attributed to the small particle size of ceria and basicity of $\mathrm{CaO}$.

\section{Conclusions}

A Co/ $/ \mathrm{CeO}_{2}$ catalyst and $\mathrm{Co} / \mathrm{CeO}_{2}$ catalysts modified with $5.0 \%, 10.0 \%$, and $15.0 \%$ calcium doping were prepared by the citric acid complexing method. The catalysts showed good activity for ethanol steam reforming, with $100 \%$ ethanol conversion into $\mathrm{C}_{1}$ species at reaction temperatures over $500{ }^{\circ} \mathrm{C}$ at a $\mathrm{GHSV}=50000 \mathrm{ml} /(\mathrm{g} \cdot \mathrm{h}), \mathrm{S} / \mathrm{C}=3.0$, and atmospheric pressure. The hydrogen yield was as high as $90 \%$ under optimized conditions. Calcium doping in the $\mathrm{Co} / \mathrm{CeO}_{2}$ catalysts reduced the ceria particle size but made them more difficult to reduce, which deteriorated oxygen storage capacity and catalytic performance when the calcium content was over $5.0 \%$. The poorer catalytic performance was probably because of a smaller $\mathrm{Co}^{0}-\mathrm{O}-\mathrm{Ce}^{3+}$ metal-oxide interface due to $\mathrm{CaO}$ fouling of $\mathrm{CeO}_{2}$. Stability investigation of the $\mathrm{Co}_{0.1} \mathrm{Ce}_{0.9} \mathrm{O}_{y}$ and $\mathrm{Co}_{0.1} \mathrm{Ce}_{0.85} \mathrm{Ca}_{0.05} \mathrm{O}_{y}$ catalysts suggested that the small particle size of ceria and weak basic property of the catalyst gave better carbon deposition resistance. Activity measurement results from catalysts pre-reduced at different temperatures suggested that $\mathrm{Ce}^{3+}$ formation was needed for ethanol steam reforming.

\section{References}

1 Navarro R M, Peña M A, Fierro J L G. Chem Rev, 2007, 107: 3952

2 Demirbas A. Prog Energy Combust Sci, 2007, 33: 1

3 Song H, Zhang L, Ozkan U S. Ind Eng Chem Res, 2010, 49: 8984

4 Song H, Zhang L, Watson R B, Braden D, Ozkan U S. Catal Today, 2007, 129: 346

5 孙杰, 吴峰, 邱新平, 王芳, 郝少军, 刘媛. 催化学报(Sun J, Wu F, Qiu X P, Wang F, Hao Sh J, Liu Y. Chin J Catal), 2004, 25: 551

6 Zhang L F, Liu J, Li W, Guo C L, Zhang J L. J Nat Gas Chem, 2009, 18: 55

7 王红, 刘鹏翔, 刘源, 秦永宁. 催化学报(Wang H, Liu P X, Liu Y, Qin Y N. Chin J Catal), 2006, 27: 976

8 杨宇, 吴绯, 马建新. 催化学报(Yang Y, Wu F, Ma J X. Chin J Catal), 2005, 26: 131

9 张保才, 李勇, 蔡伟杰, 唐晓兰, 徐奕德, 申文杰. 催化学 报(Zhang B C, Li Y, Cai W J, Tang X L, Xu Y D, Shen W J.
Chin J Catal), 2006, 27: 567

10 Vaidya P D, Rodrigues A E. Chem Eng J, 2006, 117: 39

11 马飞, 储伟, 黄利宏, 余晓鹏, 吴永永. 催化学报(Ma F, Chu W, Huang L H, Yu X P, Wu Y Y. Chin J Catal), 2011, 32: 970

12 Kugai J, Subramani V, Song C, Engelhard M H, Chin Y H. J Catal, 2006, 238: 430

13 Tosti S, Fabbricino M, Moriani A, Agatiello G, Scudieri C, Borgognoni F, Santucci A. J Membr Sci, 2011, 377: 65

14 Llorca J, de la Piscina P R, Dalmon J A, Sales J, Homs N. Appl Catal B, 2003, 43: 355

15 Llorca J, Homs N, Sales J, de la Piscina P R. J Catal, 2002, 209: 306

16 Song H, Mirkelamoglu B, Ozkan U S. Appl Catal A, 2010, 382: 58

17 Song H, Ozkan U S. J Catal, 2009, 261: 66

18 Song H, Tan B, Ozkan U S. Catal Lett, 2009, 132: 422

19 Kim D W, Oh S G. Mater Lett, 2005, 59: 976

20 张媛, 李增喜, 闻学兵, 刘源. 催化学报(Zhang Y, Li Z X, Wen X P, Liu Y. Chin J Catal), 2005, 26: 1059

21 王林, 陈顺权, 刘源. 物理化学学报(Wang L, Chen S Q, Liu Y. Acta Phys-Chim Sin), 2008, 24: 849

22 张晓亮, 王卫平, 熊国兴, 杨维慎. 催化学报(Zhang X L, Wang W P, Xiong G X, Yang W S. Chin J Catal), 2010, 31: 1049

23 Mendes D, Tosti S, Borgognoni F, Mendes A, Madeira L M. Catal Today, 2010, 156: 107

24 Basile A, Pinacci P, Iulianelli A, Broglia M, Drago F, Liguori S, Longo T, Calabro V. Int J Hydrogen Energy, 2011, 36: 2029

25 Iulianelli A, Liguori S, Longo T, Tosti S, Pinacci P, Basile A. Int J Hydrogen Energy, 2010, 35: 3159

26 Chen Y, Shao Z, Xu N. Energy Fuel, 2008, 22: 1873

27 de Lima S M, da Silva A M, da Costa L O, Graham U M, Jacobs G, Davis B H, Mattos L V, Noronha F B. J Catal, 2009, 268: 268

28 Sanchez-Sanchez M C, Yerga R M N, Kondarides D I, Verykios X E, Fierro J L G. J Phys Chem A, 2010, 114: 3873

29 Descorme C, Madier Y, Duprez D. J Catal, 2000, 196: 167

30 Duprez D, Descorme C, Birchem T, Rohart E. Top Catal, 2001, 16: 49

31 Can L, Domen K, Maruya K, Onishi T. J Am Chem Soc, 1989, 111: 7683

32 Song H, Ozkan U S. J Phys Chem A, 2010, 114: 3796

33 Pereira E B, Homsa N, Marti S, Fierro J L G, de la Piscina P R. J Catal, 2008, 257: 206

34 Granados M L, Gurbani A, Mariscal R, Fierro J L G. J Catal, 2008, 256: 172

35 de la Piscina P R, Homs N. Chem Soc Rev, 2008, 37: 2459

36 Ni M, Leung D Y C, Leung M K H. Int J Hydrogen Energy, 2007, 32: 3238

37 Cheekatamarla P K, Finnerty C M. J Power Sources, 2006, 160: 490 